\author{
Review Article \\ www.ijrap.net (ISSN:2229-3566)
}

\section{ROLE OF SHILAJIT AND TRIPHALA KWATH IN HYPOTHYROIDISM: A REVIEW} \\ Gayatri Devi ${ }^{1 *}$, Vipin Kumar $^{2}$, Sheetal Verma ${ }^{3}$ \\ ${ }^{1}$ PG Scholar, Department of Kaya Chikitsa, Uttarakhand Ayurveda University, Gurukul Campus, Haridwar, \\ Uttarakhand, India \\ ${ }^{2}$ Assistant Professor, Department of Samhita, Sanskrit Evum Siddhant, Uttarakhand Ayurveda University, Gurukul \\ Campus, Haridwar, Uttarakhand, India \\ ${ }^{3}$ Associate Professor, Department of Samhita, Sanskrit Evum Siddhant, Uttarakhand Ayurveda University, Gurukul \\ Campus, Haridwar, Uttarakhand, India
}

Received on: 26/08/20 Accepted on: 13/11/20

\begin{abstract}
*Corresponding author
E-mail: drgayatrirajput@gmail.com
\end{abstract}

DOI: $10.7897 / 2277-4343.1106186$

\begin{abstract}
Hypothyroidism is one of the burning issues in the current scenario and is affecting the lives of many people on various levels. Autoimmunity is responsible for over $90 \%$ of non-iatrogenic hypothyroidism in iodine-sufficient area. In iodine-sufficient areas, the most common cause of hypothyroidism is chronic autoimmune thyroiditis (also known as Hashimoto's disease). Subclinical hypothyroidism is a mild form of primary hypothyroidism. Signs and symptoms of hypothyroidism are weight gain, cold intolerance, fatigue, somnolence, dry skin, dry hair, menorrhagia are more common constipation, hoarseness of voice, aches and pains, muscle stiffness, deafness, depression, infertility is less common. As per Ayurveda (science of life), it is caused due to vitiation of Agni. Shilajit an exudate, contains mainly fulvic acid, humic acid, and trace element (iron, selenium) which includes anti-inflammatory, immune-stimulant, properties. Anaemia as a symptom is associated with Hypothyroidism. The constituent present in Shilajit that is Fulvic acid enhances the absorption of iron so that serum iron status increases and can be helpful in the management of hypothyroidism. Triphala is an Ayurvedic herbal formulation of dried fruits of Terminalia chebula, Terminalia bellerica and Phyllantus emblica. The major phytoconstituent of Terminalia bellerica, Terminalia chebula and Phyllantus emblica fruits is gallic acid, which is known to have a wide range of therapeutic activity, e.g. anti-atherosclerotic, cardioprotective. In this review paper, it is being established that all these characteristics of Shilajit with Triphala kwath may be the probable reason for its effect on the management of hypothyroidism.
\end{abstract}

Keywords: Hypothyroidism, Shilajit, Triphala, Anti-Inflammatory, Immune-stimulant.

\section{INTRODUCTION}

Hypothyroidism an Endocrine Disorder which has been increased with alarming speed over the years. Reduced production of thyroid hormone is the central feature of the clinical state termed Hypothyroidism. ${ }^{1,2}$ It can be primary or secondary. Primary hypothyroidism is the etiology in approximately $99 \%$ of cases of hypothyroidism. ${ }^{3}$

Subclinical hypothyroidism is a mild form of primary hypothyroidism, in which serum TSH is raised and serum $\mathrm{t} 3$ and t4 concentrations are at the lower end of the reference range. ${ }^{4}$ This may persist for many years, although there is a risk progression to overt thyroid failure, particularly if antibodies to thyroid peroxidase are present or if the TSH rises above $10 \mathrm{mlU} / \mathrm{L} .{ }^{5}$

Primary hypothyroidism is up to $8-9$ times more common in women than in men, and the prevalence increases with age, with a peak incidence between the ages of 30 and 50 years. ${ }^{6,7}$ In the united states, $0.3 \%$ have overt hypothyroidism, defined as an elevated serum TSH concentration and reduced free thyroxin concentration (fT4), and $4.3 \%$ have what has been described as subclinical or mild hypothyroidism.

In the US, hypothyroidism affects an estimated $4 \%$ of women aged 18-24 years and $21 \%$ of women older than 74 years; respective values in men are $3 \%$ and $16 \%{ }^{8}$ A UK survey determined that approximately $7.5 \%$ of women and $2.8 \%$ of men have elevated serum levels of TSH. ${ }^{9}$

\section{Cause of Primary hypothyroidism}

Iodine deficiency remains the most common cause of hypothyroidism worldwide. In iodine-sufficient areas, the most common cause of hypothyroidism is chronic autoimmune thyroiditis (also known as Hashimoto's disease). ${ }^{10}$

Hypothyroidism, which is $50 \%$ of the cases is of autoimmune etiology, is observed in chronic autoimmune thyroiditis and In the remaining $50 \%$, it is due to other causes or drugs. ${ }^{11}$ Raised concentrations of thyroid peroxidase antibodies are also detected in about $11 \%$ of the general population. ${ }^{12}$ In patients with subclinical hypothyroidism, thyroid peroxidase antibody measurements help to predict progression to overt disease. ${ }^{13,14}$

Other causes for hypothyroidism include surgical removal of thyroid tissue, radioactive iodine therapy, infiltrative destruction of thyroid tissue, drug-mediated inhibition of thyroid hormone production, and release like thionamides, lithium. ${ }^{15}$

\section{Cause of Secondary hypothyroidism}

It causes due to insufficient secretion of TRH or TSH. Hypothalamic disorders as a tumor,irradiation, inflammation (vasculitis) and hypopituitarism as mass lesions, pituitary radiation etc. ${ }^{16}$ 


\section{Ayurvedic View}

Acharya Charaka describes Galganda (goitre) under Trisothiya Adhyaya as a part of Sotharoga and in Svayathu Chikitsha Adhyaya. ${ }^{17,18}$ There, only the causes of Sotha Roga have been explained and no specific cause of Galganda (goitre) has been mentioned. In Sushruta Samhita at different places, under different topics few references for Galganda (goitre) Nidana are available. ${ }^{19,20}$

Since Charaka has mentioned Galganda (goitre) under Kapha Nanatmaja Vyadhi, the provocative factors of Kapha can also be taken as the cause of $\mathrm{it}^{21}$.

Ayurvedic Nidana is concerned about the etiological factors related to kapha-vataprakopa (provocative stage), agnimandya (diminution of agni) janaka, and srotorodha (obstructive pathology occurring in channels) nidana will be responsible for the hypothyroidism.

According to Acharya Charaka, it is not necessary that every disease manifestation must have a certain name, but it is more important to understand the possible pathogenesis of the disease in terms of involved factors like dosha, dushya. ${ }^{22}$

According to the principals of Ayurveda (science of life), we find that it is caused due to vitiation of Agni. Vitiation of jatharagni (metabolic factors located in digestive tract), which affects dhatwagni (metabolic factors located in dhātu) or independently vitiation of dhatwagni (metabolic factors located in dhātu), eventually, brings out pathology sequence and ultimately, the diseased condition developed. ${ }^{23}$ There are many systems which involve in the pathogenesis of hypothyroidism, in the context of dosha-dushya sammurchana may be considered as kapha associated pitta- dushti with vitiation of vatadosha due to margavarana and predominantly rasa-vaha, mamsa-vaha and Medovaha srotodusti can be leads condition of hypothyroidism. ${ }^{24}$

The major function of the thyroid gland is to increase the rate of chemical reaction in most cells, thus increasing metabolic rate and promotes the deposition of calcium in the bones. ${ }^{25}$ In light of Ayurvedic principals, this is attributed to the function of Agni which is an important factor for digestion and metabolic processes. The management of hypothyroidism through Ayurveda (science of life) is concerned; hormonal replacement is not possible through drugs.

However, the pathogenesis of hypothyroidism in the context of Ayurveda (science of life) one can interpret the role of Agni is foremost and through its management; the wholesome normal activity of the thyroid gland may be achieved.

The objective of treatment should be to address the problem at its root by regulating the immune system and decreasing inflammation. ${ }^{26}$ The drug Shilajit with Triphala is mentioned in Charaka Samhita for the management of Tridoshaj Shotha (oedema), which is one of the common manifestations of hypothyroidism. ${ }^{27}$

\section{Sign and symptom}

Weight gain, cold intolerance, fatigue, somnolence, dry skin, dry hair, menorrhagia, anemia are mostly common.

Constipation, hoarseness of voice, aches and pains, muscle stiffness, deafness, depression, infertility are less common. ${ }^{28}$

\section{Drug review}

\section{Triphala}

\begin{tabular}{|c|c|c|c|c|c|c|}
\hline Drug & Rasa & Guna & Virya & Vipaka & Dosha karma & $\begin{array}{c}\text { Chemical } \\
\text { composition }\end{array}$ \\
\hline Amala & $\begin{array}{c}\text { Lavanrahit Panchras } \\
\text { (Amla-pradhan) }\end{array}$ & $\begin{array}{c}\text { Guru, Ruksh, } \\
\text { Sheeta }\end{array}$ & Ushna & Madhura & $\begin{array}{c}\text { Tridoshhar } \\
\text { Visheshtah Pitta } \\
\text { Shamak }\end{array}$ & $\begin{array}{c}\text { Vitamin C, Garlic } \\
\text { Acid, Tannic Acid, } \\
\text { Linoleic Acid, } \\
\text { Indolassitate, Acetic } \\
\text { Acid }\end{array}$ \\
\hline Haritiki & $\begin{array}{c}\text { Lavanrahit Panchras } \\
\text { (Kashaya- } \\
\text { Pradhan) }\end{array}$ & Laghu, Rukshna & Ushna & Madhura & $\begin{array}{c}\text { Tridosha, } \\
\text { Vishesta } \\
\text { Vatashamak }\end{array}$ & $\begin{array}{c}\text { Chebulic acid, Tannic } \\
\text { acid, Vitamin C, } \\
\text { Oleic acid, Palmitic } \\
\text { Acid }\end{array}$ \\
\hline Bibhitaka & Kashaya & Laghu, Ruksha & Ushna & Madhura & Tridoshar & $\begin{array}{c}\text { Gallic acid, Tannic } \\
\text { acid, Ascorbic acid, } \\
\beta \text {-sitosterol }\end{array}$ \\
\hline
\end{tabular}

\section{Shilajit (Black bitumen)}

\begin{tabular}{|c|c|c|c|c|c|c|}
\hline Drug & Rasa & Guna & Virya & Vipaka & Dosha karma & Chemical composition \\
\hline Shilajit & $\begin{array}{c}\text { Tikta, } \\
\text { kashaya }\end{array}$ & $\begin{array}{c}\text { Guru, Snigdha, } \\
\text { Madhura }\end{array}$ & Sheeta & Katu & $\begin{array}{c}\text { Pacifies kapha, vata and } \\
\text { detoxifies pitta }\end{array}$ & $\begin{array}{c}\text { Fulvic Acid Hippuric acid, } \\
\text { Benzoic acid, and minerals } \\
\text { such as Iron, Aluminum, } \\
\text { Magnesium, Potassium, } \\
\text { Calcium }\end{array}$ \\
\hline
\end{tabular}


Gayatri Devi et al / Int. J. Res. Ayurveda Pharm. 11 (6), 2020

\section{Probable mode of action of Drugs}

Acharya Sushruta has described deepana property of tripahla. ${ }^{29}$ Triphala also having vatalomaka (proper regulation of excretory system), deepana (stimulation of digestive power), pachana (increasing of digestive power), rashyana, sothahar (reduced oedema) and srotoshodhaka (purification of a channel) properties. ${ }^{30}$ Hence Triphala may correct the state of Agnimandya (diminution of agni) which is a major factor in the development of hypothyroidism.

\section{Hypolipidemic effect}

Terminalia chebula (haritaki) contains b-sitosterol as the main constituent belonging to the family of phytosterols which has a similar structure as of cholesterol. ${ }^{31}$ Various foods of plant origin contain naturally this organic compound and are widely used as a food enrichment as well as a dietary supplement. ${ }^{32} \beta$-sitosterol and phytosterols inhibit the absorption of cholesterol from the digestive tract and help lower high levels of serum cholesterol..$^{33}$ Phyllantus emblica (amla) also used as an anti-atherosclerotic agent, was evaluated in rabbits fed with a cholesterol-rich diet. After 60 days the serum cholesterol, triglyceride, phospholipid, and LDL levels gotreduced by $82 \%, 66 \%, 77 \%$, and $90 \%$, respectively. ${ }^{34}$ Importantly, the aortic plaques are treated animals were regressed suggesting a potent hypolipidemic action of Phyllantus emblica is one of the risk factors for coronary artery disease which is a complication of Hypothyroidism. ${ }^{35}$

\section{Composition of Shilajit}

Shilajit contains Humic substances including Fulvic Acid, that account for around $60 \%$ to $80 \%$ of the total nutraceutical compound plus some oligo-elements including selenium of antiaging properties. ${ }^{36,37}$ Shilajit amplifies the benefit of other herbs by enhancing their bio-availability. ${ }^{38}$ Shilajit remove deepseated toxins, actively takes part in the transportation of nutrients into deep tissue, improve memory and reduces stress, recovery time in muscle, bone nerve injuries stimulate the immune system and helps to overcome chronic fatigue, lethargy which is most abundant features of hypothyroidism. ${ }^{39,40}$

\section{Anti-Inflammatory}

The presence of a high concentration of fulvic acid and humic acid reduces inflammation which prevents the toxic effect of inflammation on body tissue and improves insulin resistance. ${ }^{41}$ Shilajit also stimulates the pancreas to secrete insulin and maintains the equilibrium of catabolism and anabolism in the body. ${ }^{42}$ Thus by reducing inflammation and increasing serum insulin, Shilajit may be helpful in the reduction of symptoms, as body weight and oedema.

\section{Elemental status}

Trace elements are essential for the regulation of immunological and antioxidant functions as well as essential components or cofactors of various enzymes through metabolism. ${ }^{43}$ Trace element as selenium is required for the synthesis, activation, and metabolism of thyroid hormone. ${ }^{44}$ Anemia`s are diagnosed in 20 $60 \%$ patients with hypothyroidism. ${ }^{45}$ Shilajit, contain various trace elementalong with a higher concentration of iron, copper etc. ${ }^{46}$ along with organic materials which have the highest percentage of fulvic acid that helps in the absorption of iron into the body. ${ }^{47,48}$ Thus Shilajit has high iron concentration. Fulvic acid enhance absorption of iron so that serum iron status increases and become helpful in the management of hypothyroidism. ${ }^{49}$

\section{Immuno-stimulant}

Shilajit is very helpful in improving the immunity of the body..$^{50}$ Shilajit contains active organic molecules such as fulvic acid along with minerals. ${ }^{51}$ The fulvic acid helps in the transportation of these minerals into cells for maintaining and restoring their electrical potency, which prevents their decay and death. ${ }^{52}$ Shilajit helps in metabolism and promotes energy production in the body. ${ }^{53}$ It maintains the equilibrium of catabolism and anabolism, enhances the absorptive and detoxifying capacity of the body, and stimulates the immune systemas it is an immune-stimulant and has been found to be very effective in treating immune disorders. ${ }^{5}$

\section{CONCLUSION}

Hypothyroidism is a metabolic Endocrine disorder mainly caused by chronic autoimmune thyroiditis (also known as Hashimoto's disease). According to the principals of Ayurveda (science of life), the pathogenesis of hypothyroidism is caused due to vitiation of Agni (digestive power). Vitiation of jatharagni (metabolic factors located in digestive tract), which affects dhatwagni (metabolic factors located in dhātu) or independently vitiation of dhatwagni (metabolic factors located in dhātu), eventually, brings out the pathology sequence, and ultimately, the diseased condition develops. The pathology of hypothyroidism in the context of dosha-dushya sammurchana may be considered as Kaphadosha associated pitta- dushti with vitiation of vatadosha (doșa responsible for movement and cognition) due to margavarana and predominantly rasa-vaha, mamsa-vaha, and medovaha srotodusti occurs. Shilajit an exudate, contains mainly fulvic acid and trace element (iron,selenium) which includes antiinflammatory, immune-stimulant properties. Shilajit also possesses agnideepan, chedana, lekhana (scraping), vrishya, and yogvahi property (carrier of properties). The properties of Triphala Kwath can be amplified with the combination of Shilajit due to yogavahitwa (carrier of properties). Triphala also has hypolipidemic properties. Probably these properties of Shilajit with Triphala can check the pathological process of Hypothyroidism. Thus helpful in the management of hypothyroidism.

\section{REFERENCES}

1. Almandoz JP, Gharib H. Hypothyroidism: etiology, diagnosis, and management. Medical Clinics 2012 Mar 1; 96(2): 203-21.

2. Vaidya B, Pearce SH. Management of hypothyroidism in adults. BMJ 2008 Jul 28; 337.

3. Khandelwal D, Tandon N. Overt and subclinical hypothyroidism. Drugs 2012 Jan 1; 72(1): 17-33.

4. Stuart H. Ralston, Ian D Penam, Mark W. J Strachan, Stuart H. 2018 A.D. Davidson's Principle and Practice of Medicine (23st. ed.). Edinburgh: Churchill Livingstone/ Elsevier.chapter 18; p. 642.

5. Stuart H. Ralston, Ian D Penam, Mark W. J Strachan, Stuart H. 2018 A.D. Davidson's Principle and Practice of Medicine (23st. ed.). Edinburgh: Churchill Livingstone/Elsevier, chapter 18; p. 642.

6. Malaty W. Primary hypothyroidism. 2017. https://best practice.bmj.com/topics/en-us/535/pdf/535.pdf. Accessed 4 Jan 2017.

7. Aoki Y, Belin RM, Clickner R, Jeffries R, Phillips L, Mahaffey KR. Serum TSH and total T4 in the United States population and their association with participant characteristics: National Health and Nutrition Examination Survey (NHANES 1999-2002). Thyroid 2007 Dec 1; 17(12): 1211-23. 
8. Canaris GJ, Manowitz NR, Mayor G, Ridgway EC. The Colorado thyroid disease prevalence study. Archives of internal medicine $2000 \mathrm{Feb} 28$; 160(4): 526-34.

9. Tunbridge WM, Evered DC, Hall R, Appleton D, Brewis M, Clark F, Evans JG, Young E, Bird T, Smith PA. The spectrum of thyroid disease in a community: the Whickham survey. Clinical endocrinology 1977 Dec; 7(6): 481-93.

10. Editor J. Larry Jameson Editor, Harrison's Endocrinology, Disorders of the thyroid gland chapter 4, $3^{\text {rd }}$ Edition, McGraw-Hill Education; p. 71.

11. Kostoglou-Athanassiou I, Ntalles K. Hypothyroidism-new aspects of an old disease. Hippokratia 2010 Apr; 14(2): 82.

12. Hollowell JG, Staehling NW, Flanders WD, Hannon WH, Gunter EW, Spencer CA, Braverman LE. Serum TSH, T4, and thyroid antibodies in the United States population (1988 to 1994): National Health and Nutrition Examination Survey (NHANES III). The Journal of Clinical Endocrinology and Metabolism 2002 Feb 1; 87(2): 489-99.

13. Effraimidis G, Strieder TG, Tijssen JG, Wiersinga WM. Natural history of the transition from euthyroidism to overt autoimmune hypo-or hyperthyroidism: a prospective study. European Journal of Endocrinology 2011 Jan 1; 164(1): 107.

14. Walsh JP, Bremner AP, Feddema P, Leedman PJ, Brown SJ, O'Leary P. Thyrotropin and thyroid antibodies as predictors of hypothyroidism: a 13-year, longitudinal study of a community-based cohort using current immunoassay techniques. The Journal of Clinical Endocrinology and Metabolism 2010 Mar 1; 95(3): 1095-104.

15. Lee Goldman, Andrew I. Schafer editors Goldman-cecil medicine, Thyroid Chapter 213, 26 ${ }^{\text {th }}$ Edition, Elsevier 2019 by Lee Goldman, Andrew I. Schafer; p. 1465.

16. Lee Goldman, Andrew I. Schafer editors, Goldman-cecil medicine, Thyroid Chapter 213, $26^{\text {th }}$ Edition, Elsevier 2019 by Lee Goldman, Andrew I. Schafer; p. 1465.

17. Ravi Dutttripathi, Charaka Samhita with Vaidyamanorama Hindi Commentary, Sutra Sthana 18/21, Chaukhambha Subharati Prakashan, Varanasi; 2014. p. 278.

18. Ravi Dutttripathi, Charaka Samhita with Vaidyamanorama Hindi Commentary, Chikitsha Sthana 12/79, Chaukhambha Subharati Prakashan, Varanasi; 2013. p. 284.

19. Kaviraj Ambikadutta Shastri, Sushruta samhita with Ayurvedtatva Sandipika Hindi Commentary, sutra sthana 42/12, Chaukhambha Sanskrit Sthana, Varanasi; 2011. p. 157.

20. Kaviraj Ambikadutta Shastri, Sushruta samhita with Ayurvedtatva Sandipika Hindi Commentary, sutra sthana 45/21, Chaukhambha Sanskrit Sthana, Varanasi; 2011. p. 170.

21. Ravi Dutttripathi, Charaka Samhita with Vaidyamanorama Hindi Commentary, Sutra Sthana 20/17, Chaukhambha Subharati Prakashan, Varanasi; 2011. p. 296.

22. Ravi Dutttripathi, Charaka Samhita with Vaidyamanorama Hindi Commentary, Sutra Sthana 18/44, Chaukhambha Subharati Prakashan, Varanasi; 2011. p. 281.

23. Ravi Dutttripathi, Charaka Samhita with Vaidyamanorama Hindi Commentary, Chikitsha Sthana 15/39, Chaukhambha Subharati Prakashan, Varanasi; 2013. p. 367.

24. Mridulranjan, ramtekerajkalthakaranupB. Review on Ayurvedic management of hypothyroidism with critical analysis 2015; 3(9): 83-88.

25. John E. Hall, Gyton and Hall medical physiology, Chapter 75, $13^{\text {th }}$ Edition, by John E. Hall; p. 927.

26. Singh K, Thakar AB. A clinical study to evaluate the role of Triphaladya Guggulu along with Punarnavadi Kashaya in the management of hypothyroidism. Ayu 2018 Jan; 39(1): 50.

27. Ravi Dutttripathi, Charaka Samhita with Vaidyamanorama Hindi Commentary, Chikitsha Sthana 12/49, Chaukhambha Subharati Prakashan, Varanasi; 2013. p. 279.
28. Stuart H Ralston, Ian D Penaman, Mark W. J Strachan, 2018 A.D. Davidson's Principle and Practice of Medicine, Endocrinology Chapter $18,23^{\text {rd }}$ Edition, Elsevier publisher; p. 637.

29. Kaviraj Ambikadutta Shastri, Sushruta samhita with Ayurvedtatva Sandipika Hindi Commentary, sutra sthana 38/56, Chaukhambha Sanskrit Sthana, Varanasi; 2011. p. 145.

30. Prof. P.V. Sharma Dravyaguna, Vigyana Vol. $2,16^{\text {th }}$ edition, volume $2^{\text {nd }}$ Chaukhambha Bharti Academy; 1995.

31. Tarasiuk A, Mosińska P, Fichna J. Triphala: current applications and new perspectives on the treatment of functional gastrointestinal disorders. Chinese medicine 2018 Dec; 13(1): 39.

32. Tarasiuk A, Mosińska P, Fichna J. Triphala: current applications and new perspectives on the treatment of functional gastrointestinal disorders. Chinese medicine 2018 Dec; 13(1): 39.

33. Rudkowska I, Abu Mweis SS, Nicolle C, Jones PJ Cholesterol-lowering efficacy of plant sterols in low-fat yogurt consumed as a snack or with a meal. Journal of the American College of Nutrition 2008 Oct 1; 27(5): 588-95.

34. Mathur R, Sharma A, Dixit VP, Varma M. Hypolipidaemic effect of fruit juice of Emblica officinalis in cholesterol-fed rabbits. Journal of Ethnopharmacology $1996 \mathrm{Feb} 1$; 50(2): 61-8.

35. Mathur R, Sharma A, Dixit VP, Varma M. Hypolipidaemic effect of fruit juice of Emblica officinalis in cholesterol-fed rabbits. Journal of Ethnopharmacology 1996 Feb 1; 50(2): 61-8.

36. Khanna R, Witt M, Anwer MK, Agarwal SP, Koch BP. Spectroscopic characterization of fulvic acids extracted from the rock exudate shilajit. Organic Geochemistry 2008 Dec 1; 39(12): 1719-24.

37. Mittal P, Kaushik D, Gupta V, Bansal P, Khokra S. Therapeutic potentials of "shilajit rasayana"- A review. Int J Pharm Clin Res 2009; 1(2): 47-9.

38. Dash B. Materia Medica of Ayurveda. New Delhi: B Jain Publishers; 1991.

39. Yuan S. Application of Fulvic acid and its derivatives in the fields of agriculture and medicine. June; 1993.

40. Deo YK, Chaudary Arnand K. Shilajit for obesity. A Probable pharmacological postulates. Inj J Res Ayuverda Pharm 2015; 6(1): 69-72.

41. Deo YK, Chaudary Arnand K. Shilajit for obesity. A Probable pharmacological postulates. Inj J Res Ayuverda Pharm 2015; 6(1): 69-72.

42. Meena H, Pandey HK, Arya MC, Ahmed Z. Shilajit: A panacea for high-altitude problems. International Journal of Ayurveda Research 2010 Jan; 1(1): 37.

43. Chopra RN, Chopra IC, Handa KL, Kapur LD. Chopra's Indigenous Drugs of India. $2^{\text {nd }}$ ed. B Calcutta India: K Dhur of Academic Publishers; 1958.

44. Chandra RK, Au B. Spleen hemolytic plaque-forming cell response and generation of cytotoxic cells in genetically obese (C57B1/6J ob/ob) mice. International Archives of Allergy and Immunology 1980; 62(1): 94-8.

45. Antonijević N, Nesović M, Trbojević B, Milosević R. Anemia in hypothyroidism. Medicinskipregled 1999 Mar 1; 52(3-5): 136-40.

46. Gregoire FM, Smas CM, Sul HS. Understanding adipocyte differentiation. Physiological reviews 1998 Jan 7; 78(3): 783809.

47. Dash B. Materia Medica of Ayurveda. New delhi; B Jain publishers; 1991.

48. Sushuruta samhita with hindi commentary by Bhishagratna KK: Chowkhamba Sanskrit series office, Varanasi; 1998. 
49. Deo YK, Chaudary Arnand K. Shilajit for obesity. A Probable pharmacological postulates. Inj J Res Ayuverda Pharm 2015; 6(1): 69-72.

50. Meena H, Pandey HK, Arya MC, Ahmed Z. Shilajit: A panacea for high-altitude problems. International Journal of Ayurveda Research 2010 Jan; 1(1): 37.

51. Meena H, Pandey HK, Arya MC, Ahmed Z. Shilajit: A panacea for high-altitude problems. International Journal of Ayurveda Research 2010 Jan; 1(1): 37.

52. Meena H, Pandey HK, Arya MC, Ahmed Z. Shilajit: A panacea for high-altitude problems. International Journal of Ayurveda Research 2010 Jan; 1(1): 37.
53. Meena H, Pandey HK, Arya MC, Ahmed Z. Shilajit: A panacea for high-altitude problems. International Journal of Ayurveda Research 2010 Jan; 1(1): 37.

54. Meena H, Pandey HK, Arya MC, Ahmed Z. Shilajit: A panacea for high-altitude problems. International Journal of Ayurveda Research 2010 Jan; 1(1): 37.

\section{Cite this article as:}

Gayatri Devi et al. Role of Shilajit and Triphala Kwath in Hypothyroidism: A Review. Int. J. Res. Ayurveda Pharm. 2020;11(6):64-68 http://dx.doi.org/10.7897/2277-4343.1106186

\section{Source of support: Nil, Conflict of interest: None Declared}

Disclaimer: IJRAP is solely owned by Moksha Publishing House - A non-profit publishing house, dedicated to publishing quality research, while every effort has been taken to verify the accuracy of the content published in our Journal. IJRAP cannot accept any responsibility or liability for the site content and articles published. The views expressed in articles by our contributing authors are not necessarily those of IJRAP editor or editorial board members. 